\title{
Functional Analysis of a Human Tumor Necrosis Factor $\alpha$ (TNF- $\alpha$ ) Promoter Polymorphism Related to Joint Damage in Rheumatoid Arthritis
}

\author{
Eric L. Kaijzel, ${ }^{1}$ Michiel V. van Krugten, ${ }^{1}$ \\ Brigitta M. N. Brinkman,' ${ }^{\prime}$ Tom W. J. Huizinga,' \\ Tahar van der Straaten, ${ }^{\prime}$ J. Mieke W. Hazes, ${ }^{1}$ \\ H. W. Loems Ziegler-Heitbrock, ${ }^{2}$ Sergei A. Nedospasov, ${ }^{3,4}$ \\ Ferdinand C. Breedveld, ${ }^{1}$ and Cornelis L. Verweij ${ }^{1}$ \\ ${ }^{1}$ Department of Rheumatology, Leiden University Medical Center, \\ Leiden, The Netherlands \\ ${ }^{2}$ Institute for Immunology, University of Munich, Munich, Germany \\ ${ }^{3}$ Engelhardt Institute of Molecular Biology and Belozersky Institute of \\ Physico-Chemical Biology, Moscow, Russia \\ ${ }^{4}$ Intramural Research Support Program, SAIC Frederick, National \\ Cancer Institute-Frederick Cancer Research and Development \\ Center, Frederick, Maryland, U.S.A.
}

\begin{abstract}
Background: Functional heterogeneity in the tumor necrosis factor $\alpha$ (TNF- $\alpha$ ) gene may be responsible for the TNF- $\alpha$ response in infectious and autoimmune diseases. Recently, the TNF-238 promoter polymorphism was observed as being associated with a more destructive disease in rheumatoid arthritis (RA). To determine the relation between TNF-238 and disease progression, the extent of joint destruction in a cohort of $101 \mathrm{RA}$ patients followed for 12 years was analyzed. Furthermore, we have attempted to link this polymorphism to TNF- $\alpha$ gene transcription in monocytes and lymphocytes in vitro.

Patients, Materials, and Methods: The extent of joint destruction determined on $\mathrm{X}$-rays of hands and feet assessed after $0,3,6$, and 12 years was compared with TNF-238 genotypes. Functional consequences of TNF- $\alpha$ gene polymorphisms using reporter gene constructs were analyzed in cells of the monocyte and lymphocyte lineage by means of transient transfection systems.
\end{abstract}

\section{Introduction}

The cytokine tumor necrosis factor (TNF) $\alpha$ has an essential role in the inflammatory response. In dysregulated inflammation, such as rheu-
Results: The rate of joint damage in -238GA patients was lower than that in the -238GG patients, independent of HLA-DR4. Damage after 12 years was $76 \pm 30$ for the $-238 \mathrm{GA}$ versus $126 \pm 13$ for the $-238 \mathrm{GG}$ patients as determined by the van der Heijde's modification of Sharp's method. Furthermore, TNF-238A was found to be in linkage disequilibrium with an additional polymorphism at position -376 . Functional assays revealed no significant differences in the level of inducible reporter gene expression between the TNF-238/-376 promoter constructs in the cell types tested.

Conclusion: In a prospective study, we show that the TNF-238GG genotype contributes to progression of joint destruction in RA, independent of the presence of HLADR4. However, in vitro transfection assays indicate that TNF-238A by itself or in combination with TNF-376A is not likely to be of direct functional relevance for transcriptional activation. Therefore, these polymorphisms may serve as markers for additional polymorphisms in the TNF/LT locus or neighboring genes that may influence disease severity. matoid arthritis (RA), TNF- $\alpha$ is directly implicated in the pathogenesis. The most compelling evidence stems from studies in which remarkable clinical benefit was observed in RA patients treated with anti-TNF- $\alpha$ antibodies $(1,2)$. 
Since the consequence of TNF- $\alpha$ production is believed to depend on the timing, localization, and extent of its release, the tight control of TNF- $\alpha$ production may be critical to mount a proper immune response. In support of this idea, deregulated TNF- $\alpha$ expression in transgenic mice led to the induction of a symmetric polyarthritis similar to RA (3). Moreover, mice with one of the TNF alleles deleted $\left(\mathrm{TNF}^{+-}\right.$) showed increased susceptibility to high-dosage lipopolysaccharide (LPS) lethality and infectious agents, which suggest the biological consequences of differences in gene dosage $(4,5)$.

The regulation of TNF- $\alpha$ production is celltype specific and tightly controlled at multiple levels including transcription, mRNA stabilization, translation, and precursor processing. Sequences at the $5^{\prime}$ end of the gene are crucial for the control of transcription $(6,7)$. Sequences in the $3^{\prime}$ UTR are implicated in regulating mRNA stability and translational efficiency of the mRNA (reviewed in refs. 8,9).

The search for genetic heterogeneity within the TNF- $\alpha$ gene has disclosed several polymorphisms in the $5^{\prime}$ regulatory region. In RA, genetic factors influence the extent of joint damage. RA patients who are DR4 positive suffer from a more severe disease course than those who are DR4 negative (10). The TNF- $\alpha$ promoter polymorphism at position -238 (11) has been associated with disease severity independent of HLA-DR. In a case-control study, a relationship was found between the TNF-238GG genotype and a more destructive disease course and earlier disease onset in RA $(12,13)$. Consistent with these findings, the TNF-238GA genotype tends to correlate with less severe disease in multiple sclerosis (14). In systemic lupus erythematosus, the TNF-238AA genotype was found to be a marker of a particular clinical subtype (15). Furthermore, associations of the TNF-238 polymorphism with juvenile onset psoriasis and psoriatic arthritis (16), the occurrence of scarring thrachoma (17), and susceptibility to alcoholic steatohepatitis have

The content of this publication does not necessarily reflect the views or policies of the Department of Health and Human Services, nor does mention of trade names, commercial products, or organizations imply endorsement by the U.S. Government.

B. M. N. Brinkman's current address is Center for Blood Research, Boston, MA.

Address correspondence and reprint requests to: Dr. Cornelis L. Verweij, Dept. of Rheumatology, Leiden University Medical Center, Building 1, C4R, P.O. Box 9600, 2300 RC Leiden, The Netherlands. Phone: 3171 5263598; Fax: 31

71 5266752; E-mail: verweij_c@rullf2.medfac.leidenuniv.nl been reported (18). Considering the location of this polymorphism in a region involved in TNF- $\alpha$ gene transcription and its association with disease, we hypothesized that the $-238 \mathrm{G}$ to A transition might influence TNF- $\alpha$ mRNA expression and as a result, facilitate deregulation of the cytokine network, thereby influencing the disease process. In order to extend the association between the -238GG genotype and joint destruction, the relation between the TNF-238 promoter polymorphism and the progression of joint erosions was determined in a prospective study. To determine whether the -238 polymorphism has functional relevancy, we measured the activity of the allelic TNF- $\alpha$ promoters in their capacity to drive reporter gene expression in transient transfection experiments.

\section{Patients, Materials, and Methods}

\section{Patients and Healthy Controls}

From a previously reported cohort study (19), genomic DNA was available from 101 patients. These patients, ages $20-50$ years, had visited the outpatient clinic of the Leiden University Medical Center with symptoms of recent-onset RA for the first time between 1982 and 1986. All patients fulfilled the American College of Rheumatology criteria of 1987 for RA (20). Five RA patients were heterozygous $-238 \mathrm{GA}$ and $96 \mathrm{RA}$ patients were $-238 \mathrm{GG}$. Clinical data concerning the presence or absence of increased serum levels of rheumatoid factor were collected from the patients' files. Radiographs of hands and feet were taken at study entry and after 3, 6, and 12 years. The hand and foot radiographs were scored separately according to the van der Heijde modification of Sharp's method (21), random through time. This method reflects erosions and joint-space narrowing in 44 joints. The principal measure, the total score, is the sum of erosions and ranges from 0 to 448. During the follow-up period, 30 out of 101 patients did not develop erosions. Moreover, most of these patients showed no signs of arthritis after 1 year during the follow-up. To test the effect of the TNF-238 polymorphism in patients with definite erosive RA, a second analysis was carried out in the subgroup of patients $(n=71)$ with erosive disease (Sharp score $>5$ ).

The typing of TNF-238 and -376 alleles for linkage disequilibrium analysis was carried out in 403 unrelated healthy Dutch Caucasians. 


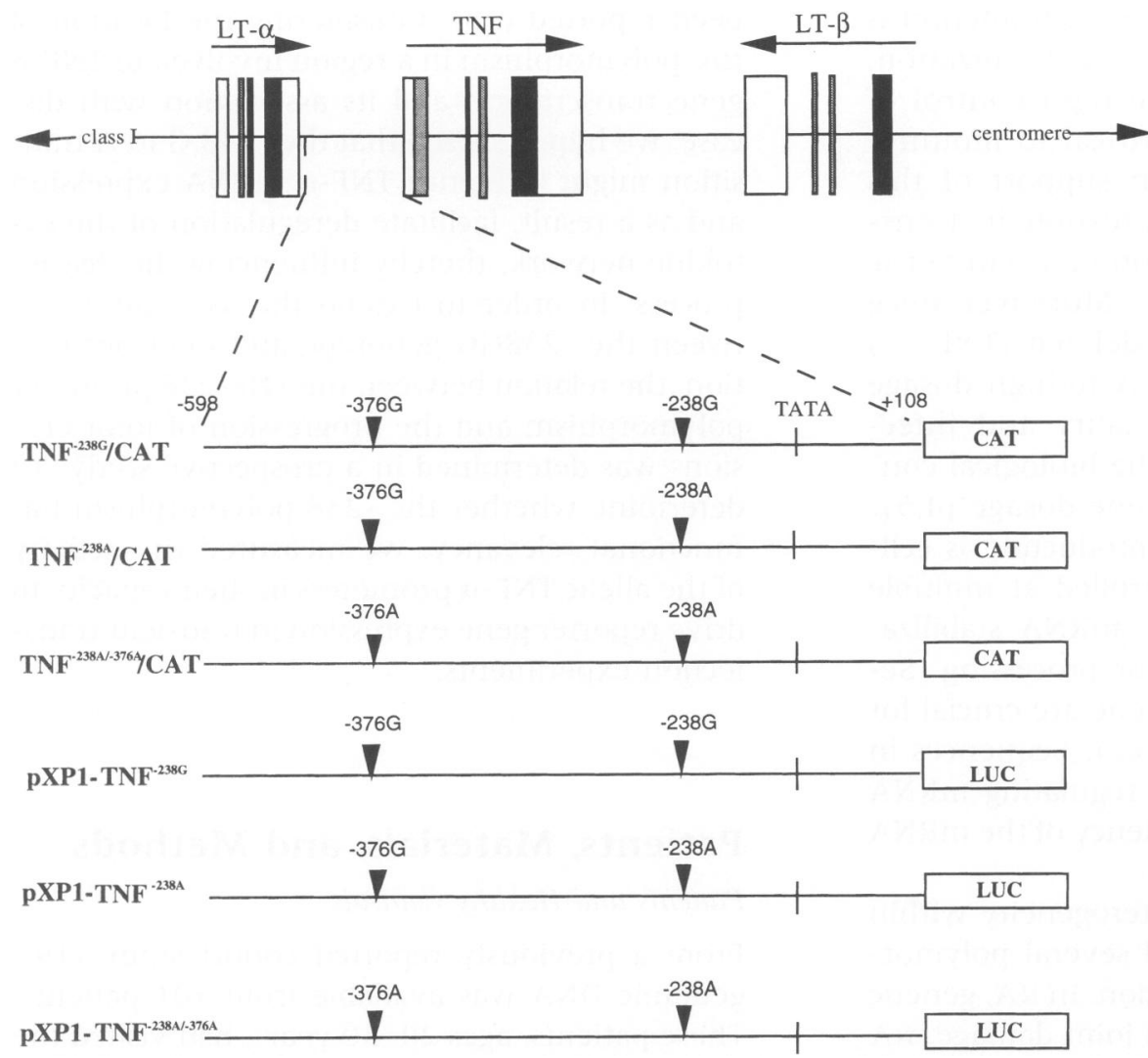

Fig. 1 Schematic representation of the human TNF/LT locus within MHC on chromosome 6 and the reporter gene constructs used in this study. Horizontal arrows indicate the direction of transcription.

DNA Isolation, HLA-DR4 Typing, PCR, Allelespecific Hybridization

Isolation of genomic DNA, typing of HLA-DR4, and assessment of TNF- $\alpha$ genotype was carried out as described previously (12).

\section{DNA Constructs}

Generation of the wild-type TNF- $\alpha$ promoterCAT construct $\mathrm{TNF}^{-238 \mathrm{G}} / \mathrm{CAT}$ containing the TNF- $\alpha$ promoter fragment from -598 to +108 has been described previously (22). The allelic TNF- $\alpha$-CAT constructs containing the relevant nucleotide substitutions at positions -238 and -376, $\mathrm{TNF}^{-238 \mathrm{~A}} / \mathrm{CAT}$, and $\mathrm{TNF}^{-238 \mathrm{~A} /-376 \mathrm{~A}} / \mathrm{CAT}$, were generated by recloning a 495 bp XmaI-Sst I TNF- $\alpha$ PCR product from -602 to -107 containing an $\mathrm{A}$ at position -376 and/or at position -238 into $\mathrm{TNF}^{-238 \mathrm{G}} / \mathrm{CAT}$. The allelic TNF-luciferase constructs were generated by cloning the $713 \mathrm{bp}$ BamHI-HindIII $\mathrm{TNF}^{-238 \mathrm{G}} / \mathrm{CAT}, \mathrm{TNF}^{-238 \mathrm{~A}} / \mathrm{CAT}$, and $\mathrm{TNF}^{-238 \mathrm{~A} /-376 \mathrm{~A}} / \mathrm{CAT}$ fragment into the $\mathrm{pXP1}$ luciferase plasmid (23), giving rise to the plasmids pXP1-TNF ${ }^{-238 \mathrm{G}}$, pXP1-TNF ${ }^{-238 \mathrm{~A}}$, and $\mathrm{pXP1-}$

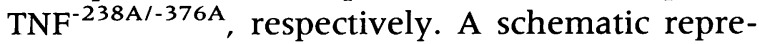
sentation of the constructs is depicted in
Figure 1. Cloning procedures and $\mathrm{CsCl}$-gradient DNA preparations were carried out using standard laboratory techniques (24). All polymorphisms were confirmed by dideoxy sequencing.

\section{Cell Culture, Activation, and Transfection}

The cell lines U937 and Mono Mac 6, representatives of the early and mature stages of monocytic differentiation, respectively, were maintained in LPS-free RPMI-1640 medium with $10 \%$ fetal calf serum (FCS; Gibco, BRL) and supplements $(25,26)$. Both cell lines were transfected by electroporation using a gene pulser (Bio-Rad, Richmond, CA) at 200 volts and 950 $\mu \mathrm{F}$ in the presence of $15 \mu \mathrm{g}$ of pXP1-TNF- $\alpha$ firefly luciferase test plasmid. As a control for transfection efficiency, $2.5 \mu \mathrm{g}$ of pRL-SV40 plasmid expressing Renilla luciferase (Promega, Leiden, The Netherlands) was cotransfected.

Twenty-four hours after transfection, Mono Mac 6 cells were activated with LPS $(1 \mu \mathrm{g} / \mathrm{ml})$ and U937 cells with a combination of LPS (1 $\mu \mathrm{g} / \mathrm{ml}$ ) and phorbol myristate acetate (PMA) $(0.01 \mu \mathrm{g} / \mathrm{ml})$. Cells were harvested $4 \mathrm{~h}$ later and luciferase activity of the plasmids was measured 
in a luminometer using the Dual-Luciferase reporter assay system (measuring both firefly and Renilla luciferase) as directed by the manufacturer (Promega).

The T cell line Jurkat and B cell line Raji were grown and transfected with TNF- $\alpha$-CAT test plasmids as previously described (22). Twenty-four hours after transfection, Raji B cells were activated with PMA $(0.05 \mu \mathrm{g} / \mathrm{ml})$ and Jurkat T cells with a combination of PMA $(0.01 \mu \mathrm{g} / \mathrm{ml})$ and $\alpha \mathrm{CD} 3$ monoclonal antibody (CLB-T3/4.1; $0.25 \mu \mathrm{g} / \mathrm{ml}$, kindly provided by L. Aarden, CLB Amsterdam). Cells were harvested $24 \mathrm{~h}$ later and CAT assays were carried out as previously described (22). As a control of transfection efficiency, luciferase activity of a cotransfected RSV-luciferase plasmid was measured in a luminometer.

\section{Statistical Analysis}

The difference between the -238GA and the -238GG group regarding the rate of joint damage as judged by the Sharp score was calculated by regression analysis using mixed model ANOVA.

Pair-wise linkage disequilibrium analysis was carried out according to the maximum likelihood procedure, with the iterative process outlined by Hill (27) as described by Meulenbelt et al. (28).

Statistical significance of the transfection data was tested using a one-way ANOVA. Values are expressed as the means $\pm \mathrm{SD}$.

\section{Results}

Association of TNF-238A with Radiographic Damage in a Prospective Cohort of RA Patients

In 101 patients who had ever fulfilled the classification criteria of RA, the joint damage was lower in the -238GA patients than in the -238GG patients. The median radiographic damage score for TNF-238GA patients $(n=5)$ was 5 at onset and changed to 31 at 3 years, 24 at 6 years, and 79 at 12 years. TNF-238GG patients $(n=96)$ showed an increased median radiographic damage score: 0 at onset, which increased to 29 at 3 years, 52 at 6 years, and 111 at 12 years. Analysis of the individual patients revealed that $30 \%$ of the patients developed no erosions (as can be seen by a large difference in mean Sharp score and median Sharp score; Table 1). Since this may reflect disease heterogeneity, the patients with erosive RA who also had persistent arthritis were analyzed separately. In these 71 patients, a clear association between the TNF-238 promoter polymorphism and rate of joint damage was observed (Table 1). The median radio- graphic damage score for TNF-238 GA patients ( $n=$ 4) was 16 at onset and changed to 40 at 3 years, 51 at 6 years, and 90 at 12 years. TNF-238 GG patients $(n=$ 67) showed an increased median radiographic damage score: 0 at onset, which increased to 42 at 3 years, 90 at 6 years, and 165 at 12 years. Analysis with repeated measures ANOVA revealed significant differences in the rate of joint damage between the groups tested: 6.2 damage units/year for the TNF238GA patients compared to 13.8 damage units/year for TNF-238GG RA patients $(p=0.026)$. Since the HLA-DR4 allele is known to be associated with a more severe disease course, the association of TNF238GG with erosive RA might be secondary to HLADR4. Subgroup analysis in the three DR4 ${ }^{-}-238 G A$ patients compared to DR4 ${ }^{-}-238 \mathrm{GG}$ patients revealed a similar rate of joint damage. Regression analysis revealed that after correction for HLA-DR4, the rate of joint damage in TNF-238GA RA patients remained significantly lower than that in the TNF-238GG group $(p=0.022)$. These data confirm the observation that TNF-238GG and HLA-DR4 are independent risk factors.

\section{TNF-238A and -376A Are in Strong Linkage Disequilibrium}

Previously, data were reported that suggested a complete linkage between the $-238 \mathrm{~A}$ and -376A position (29). To document the linkage between the two TNF- $\alpha$ promoter alleles, we determined the -238 and -376 genotypes in a large panel of healthy individuals $(n=403)$ (Table 2). The data revealed that approximately $12 \%$ (4 out of 33 ) of individuals carrying the $-238 \mathrm{~A}$ allele are also positive for the -376A allele, whereas individuals who carried the $-376 \mathrm{~A}$ allele were always carrying the -238A allele. Haplotype analysis according to Hill (27) revealed that the $-238 \mathrm{~A}$ and $-376 \mathrm{~A}$ are in strong positive linkage disequilibrium $(\Delta$ $=0.342, p<0.001)$.

\section{Consequences of TNF-238/-376 Promoter} Polymorphisms on TNF- $\alpha$ Promoter Activity in U937, Mono Mac 6, Jurkat T, and Raji B Cells

A series of reporter gene plasmids have been constructed to determine the functional consequences of the -238/-376 polymorphism on TNF- $\alpha$ gene regulation. Therefore, the polymorphic TNF- $\alpha 5^{\prime}$ regulatory region, spanning from -598 to +108 , has been fused to the CAT or luciferase reporter gene. To compare the transcriptional activity of the allelic TNF- $\alpha$ 
Table 1. Characteristics of female RA patients analyzed in a prospective case-control study

\begin{tabular}{|c|c|c|c|c|}
\hline TNF Genotype & \multicolumn{2}{|c|}{ TNF-238GA } & \multicolumn{2}{|c|}{ TNF-238GG } \\
\hline \multicolumn{5}{|c|}{ Cohort of 101 RA patients who had ever fulfilled the ACR criteria } \\
\hline No. of patients & \multicolumn{2}{|c|}{5} & \multicolumn{2}{|c|}{96} \\
\hline$\%$ Increased RF levels & \multicolumn{2}{|c|}{75} & \multicolumn{2}{|c|}{70} \\
\hline \multirow[t]{2}{*}{$\%$ HLA-DR $^{+}$} & \multicolumn{2}{|c|}{20} & \multicolumn{2}{|c|}{45} \\
\hline & \multicolumn{4}{|c|}{ Sharp Score } \\
\hline Study Entry (years) & Mean $\pm \mathrm{SD}$ & Median & Mean $\pm S D$ & Median \\
\hline 0 & $13 \pm 10$ & 5 & $7 \pm 2$ & 0 \\
\hline 3 & $35 \pm 16$ & 31 & $47 \pm 6$ & 29 \\
\hline 6 & $45 \pm 22$ & 24 & $77 \pm 9$ & 52 \\
\hline 12 & $76 \pm 30$ & 79 & $126 \pm 13$ & 111 \\
\hline
\end{tabular}

Subgroup of 71 RA patients who suffered from definite erosive RA.

$\begin{array}{lrr}\text { No. of patients } & 4 & 67 \\ \% \text { Increased RF levels } & 75 & 82 \\ \% \text { HLA-DR4 }{ }^{+} & 25 & 51\end{array}$

Sharp Score

\begin{tabular}{lrrrr} 
Study Entry (years) & Mean \pm SD & Median & Mean \pm SD & Median \\
\cline { 2 - 5 } & & 16 & $9 \pm 3$ & 0 \\
3 & $44 \pm 12$ & 40 & $61 \pm 7$ & 42 \\
6 & $57 \pm 24$ & 51 & $99 \pm 10$ & 90 \\
12 & $94 \pm 31$ & 90 & $164 \pm 14$ & 165 \\
\hline
\end{tabular}

Table 2. Genotype frequencies of polymorphisms at positions -238 and -376 in a group of 403 healthy individuals

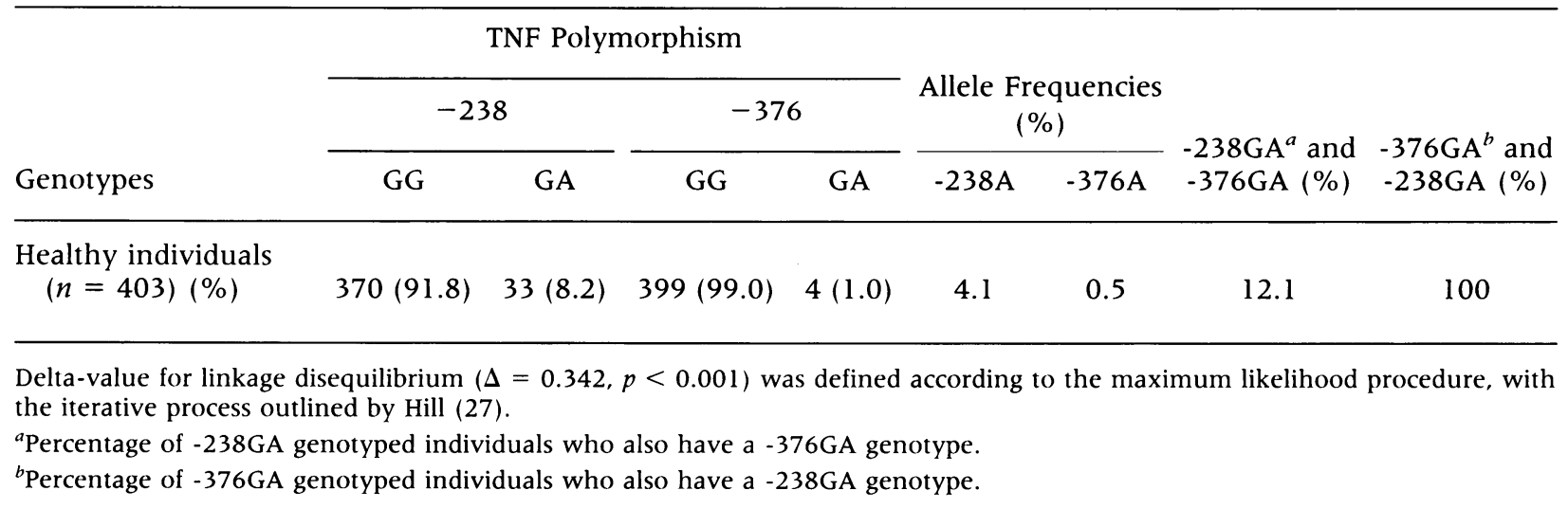




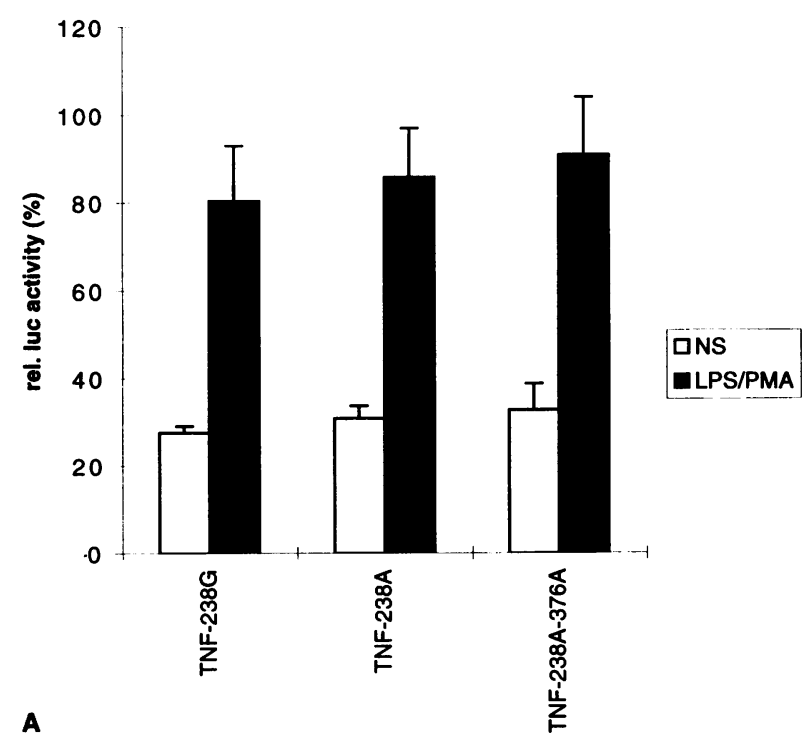

Fig. 2 Functional analysis of the pXP1-TNF ${ }^{-238 G}$, pXP1-TNF ${ }^{-238 A}$, or PXP1-TNF ${ }^{-238 A-376 A}$ plasmids in U937 (A) and Mono Mac 6 cells (B). Twentyfour hours after transfection, U937 and Mono Mac 6 were mock stimulated (NS) or induced for $4 \mathrm{hr}$ with LPS/PMA and LPS, respectively. Shown here are the means of three separate transfections with two dif-

promoters, U937 and Mono Mac 6 cells were transiently transfected with the luciferase reporter gene constructs pXP1-TNF ${ }^{-238 G}$, pXP1-TNF ${ }^{-238 \mathrm{~A}}$, and pXP1-TNF ${ }^{-238 \mathrm{~A} /-376 \mathrm{~A}}$. Subsequently, U937 and. Mono Mac 6 cells were stimulated with LPS/PMA and LPS, respectively. Luciferase activity of the constructs was expressed as the relative activity of the construct with the highest activity $(100 \%)$ in each experiment. The different TNF- $\alpha$ promoter variants did not affect constitutive or stimulated TNF- $\alpha$ gene expression in U937 and Mono Mac 6 cells (Fig. 2).

For analysis of TNF- $\alpha$ promoter activity in a $\mathrm{T}$ and $\mathrm{B}$ cell background, Jurkat and Raji cells were transiently transfected with the allelic TNF- $\alpha$ promoter/enhancer constructs driving the CAT reporter gene and stimulated with $\alpha \mathrm{CD} 3 / \mathrm{PMA}$ and PMA, respectively. CAT activity of the constructs was expressed as the relative activity of the construct with the highest activity $(100 \%)$ in each experiment. The different TNF- $\alpha$ promoter variants did not affect constitutive or stimulated TNF- $\alpha$ gene expression in Jurkat and Raji cells (Fig. 3).

In conclusion, these results reveal no significant differences in transcriptional activity between the TNF-238G, TNF-238A, and TNF-238A/-376A

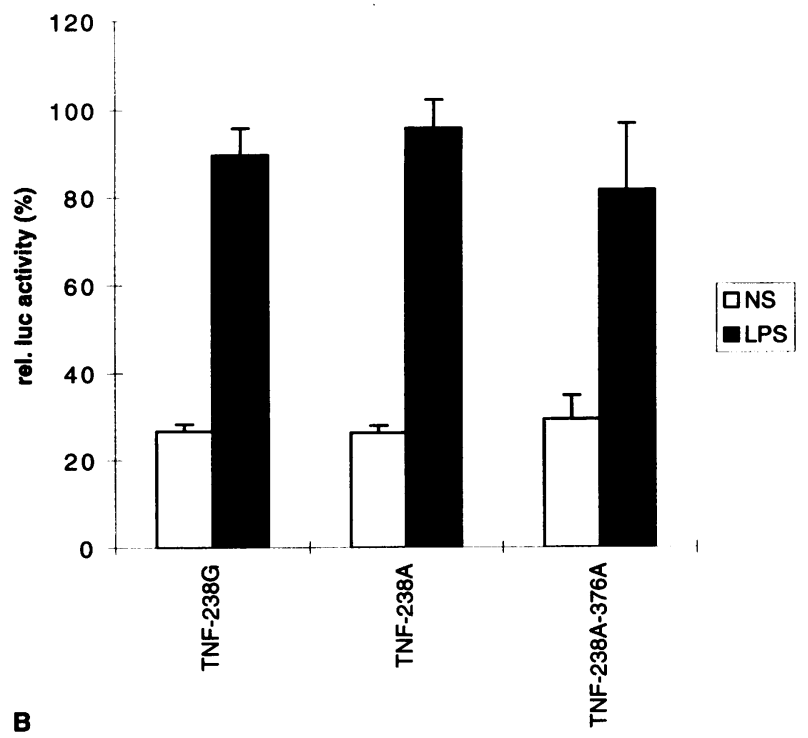

ferent batches of plasmid DNA. The luciferase constructs were always tested simultaneously. Luciferase activity of the constructs is expressed as the relative activity of the plasmid with the highest activity $(100 \%)$ reached at $4 \mathrm{hr}$ after stimulation in each experiment. Relative luciferase activities $( \pm$ SD) were averaged and plotted in histograms as depicted.

promoter/enhancers in U937, Mono Mac 6, Jurkat $\mathrm{T}$, and Raji B cells.

\section{Discussion}

The major histocompatibility complex (MHC) region contains genes whose products fulfil a role in the immune response. The importance of this region is exemplified by the long list of pathologies linked to MHC alleles. Previously, we identified the TNF-238GG genotype as a genetic factor that contributes to radiologically detected erosions in RA in a case-control study (12). This study was retrospective and it measured only one parameter (the number of erosive joints in the hands after 3 years). Therefore, we determined the progression of joint damage in a prospective cohort of 101 RA patients. The rate of joint damage in -238GA patients was lower than that in the -238GG patients, independent of HLA-DR4. Damage after 12 years was $76 \pm 30$ for the $-238 \mathrm{GA}$ versus $126 \pm 13$ for the $-238 \mathrm{GG}$ patients. This cohort consisted of patients who fulfilled the classification criteria for RA at start of disease and were followed for 12 years even if they did not show any signs of arthritis after the first year. This resulted in a relatively large sub- 


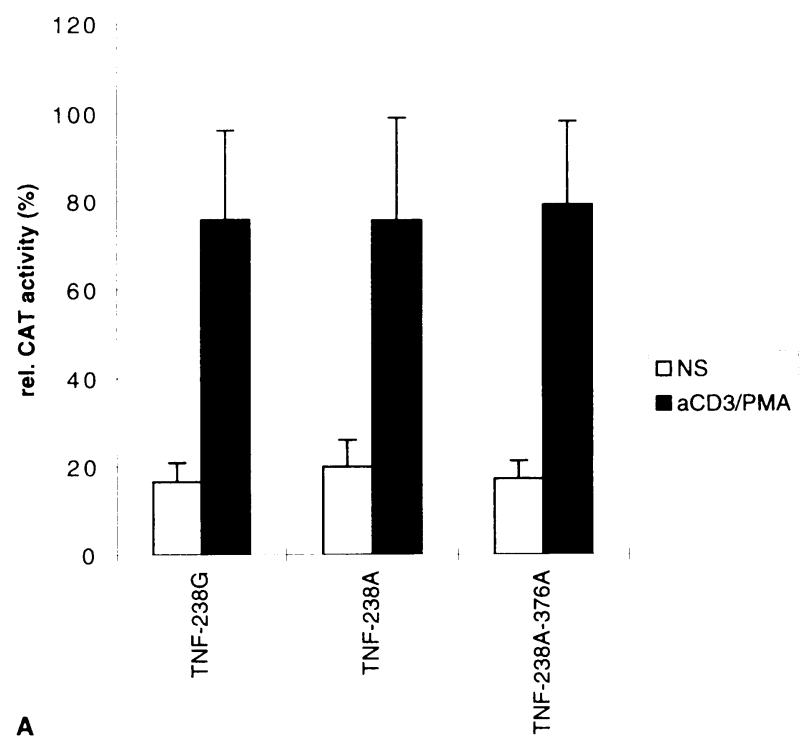

Fig. 3 Functional analysis of the $\mathrm{TNF}^{-238 G} / \mathrm{CAT}$, $\mathrm{TNF}^{-238 \mathrm{~A}} / \mathrm{CAT}$, or $\mathrm{TNF}^{-238 \mathrm{~A} /-376 \mathrm{~A}} / \mathrm{CAT}$ plasmids in Jurkat T cells (A) and Raji B cells (B). Twentyfour hours after transfection, Jurkat and Raji cells were mock-stimulated (NS) or induced for $24 \mathrm{hr}$ with $\alpha$ CD 3/PMA and PMA, respectively. Shown are the means of six (Jurkat) and three (Raji) separate transfections with three different batches of plasmid

group of patients without any erosions. In the analysis of joint damage, neither the median nor the mean joint damage gave a good reflection of a subgroup. Since patients with a nonerosive disease of limited duration may well represent heterogeneity in the pathophysiology of the disease, we also analyzed the patients who developed erosions separately. In this group of 71 erosive RA patients, the difference in the rate of joint destruction between -238GA and -238GG RA patients was even increased: damage after 12 years was $94 \pm 31$ for the $-238 \mathrm{GA}$ patients versus $164 \pm 14$ for the $-238 \mathrm{GG}$ patients. These findings support and consolidate our previous report on the -238GG TNF- $\alpha$ genotype being a new genetic factor that contributes to the progression of radiologically detected joint destruction in RA.

Linkage disequilibrium between polymorphic genes within the MHC makes it difficult to identify a specific allele that directly contributes to an observed disease association. Since joint damage results from dysregulation of inflammation, the assumption that functional heterogeneity in the TNF- $\alpha$ gene may result in differences in regulation of inflammation in $\mathrm{RA}$ is attractive. Moreover, association of TNF-238 alleles with disease outcome in other diseases, such as psori-

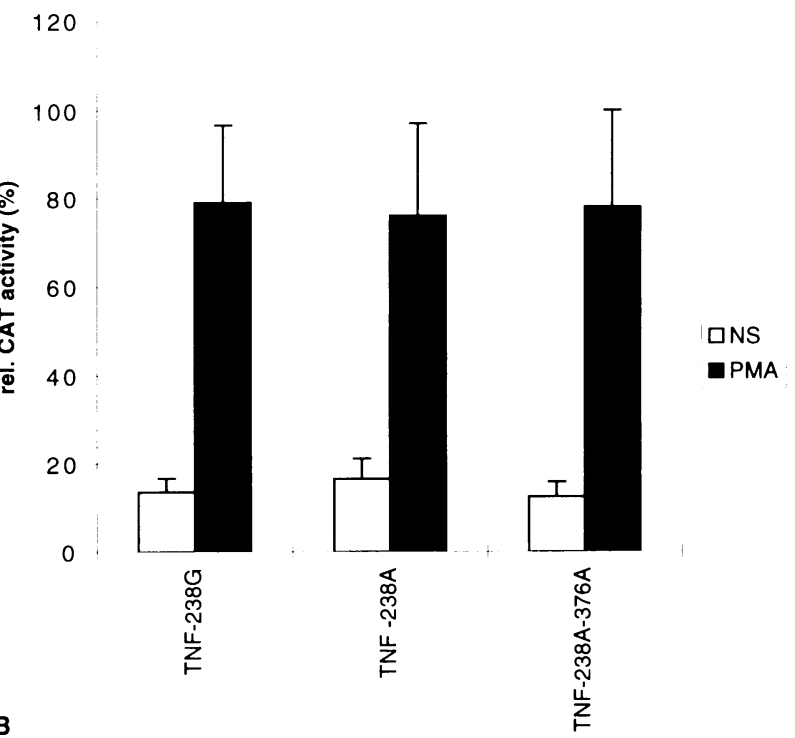

DNA. The CAT constructs were always tested simultaneously. CAT activity of the plasmids is expressed as the relative activity of the plasmid with the highest activity $(100 \%)$ reached at $24 \mathrm{hr}$ after stimulation in each experiment. Relative CAT activities ( \pm $\mathrm{SD})$ were averaged and plotted in histograms as depicted.

asis and psoriatic arthritis (16), systemic lupus erythematous (SLE) (30), scarring thrachoma (17), and alcoholic steatohepatitis (18) has strengthened the speculation on its functionality. Initial reports have suggested an effect of the TNF-238 polymorphism upon TNF- $\alpha$ gene regulation is based on similarity of the sequence encompassing -238 with a Y-box enhancer motif (11). Moreover, deletion of the sequence from -254 to -230 dramatically influenced TNF- $\alpha$ enhancer activity (31), which is indicative of the presence of a functional motif in this region. Here we have shown that a comparison of transcriptional activity of the -238 allelic TNF- $\alpha$ enhancer/promoter regions did not reveal significant differences when tested in monocytes, and $\mathrm{B}$ and $\mathrm{T}$ cells. This observation excludes a role of the -238 position in the activity of putative functional elements encompassing this position.

Pair-wise linkage disequilibrium analysis revealed that the $-376 \mathrm{~A}$ and $-238 \mathrm{~A}$ polymorphisms are in strong positive linkage disequilibrium. Since the possibility exists that the allele carrying the $-376 \mathrm{~A}$ and $-238 \mathrm{~A}$ positions could affect TNF- $\alpha$ gene transcription, a construct carrying the G-to-A transition at positions -376 and -238 was tested. No significant difference was ob- 
served for this construct compared to the $-238 \mathrm{~A}$ and wild-type allelic TNF- $\alpha$ enhancer/promoter constructs. Moreover, we have tested TNF- $\alpha$ constructs containing an extended upstream region from -1173 to +130 (32) to determine whether upstream TNF- $\alpha$ sequences could influence the transcriptional activity of -238 alleles. In analogy to the $-598 /+108$ reporter gene constructs, the $-1173 /+130-238 \mathrm{~A}$ and $-238 \mathrm{G}$ driven reporter gene expression was found to be essentially equivalent when assayed by transient transfection into Mono Mac 6 and the murine macrophage cell line ANA-1 (data not shown). This suggests that the TNF-238 polymorphism neither contributes by itself nor synergizes with the upstream region to influence TNF- $\alpha$ gene transcription.

In this study, we have tested the allelic promoter constructs in cell lines representative of monocytes and $\mathrm{T}$ and $\mathrm{B}$ cells in combination with the standard in vitro TNF- $\alpha$-inducing stimuli LPS/PMA, $\alpha$ CD3/PMA, and PMA, respectively. A functional difference between an $A$ and $a$ at position -238 might become prominent with a physiological TNF- $\alpha$-inducing stimulus, which may be different from the stimuli used in this study. In this respect, it is worth mentioning that the association between HLA-DR alleles and TNF- $\alpha$ producer phenotypes was assigned with standard in vitro TNF- $\alpha$-inducing stimuli similar to those we used $(33,34)$. Hence, application of these stimulation conditions in reporter gene studies may be expected to disclose a functional TNF- $\alpha$ gene polymorphism.

TNF- $\alpha$ is known to boost its own production by a positive feedback on its own gene expression (35). Through this mechanism, a minor difference in the initial TNF- $\alpha$ response is amplified in an in vivo system. This phenomenon is exemplified in studies performed with mice heterozygous for a deletion of the TNF- $\alpha$ gene $\left(\mathrm{TNF}^{+/-}\right)$, which revealed that a small reduction of $50 \%$ of the initial TNF- $\alpha$ gene expression gives a phenotype due to a nonlinear response in TNF- $\alpha$ levels $(4,5)$. In line with this reasoning, the possibility that the presence of relatively small, nonsignificant differences in allelic activity might be enough to elicit a biological effect in an in vivo system cannot be excluded. It is therefore relevant to note that the absence of a direct effect of TNF-238 on TNF- $\alpha$ enhancer/promoter activity is in agreement with a previous study showing that monocytes derived from TNF-238GA healthy individuals did not significantly differ in their in vitro TNF- $\alpha$ production capacity compared to that of TNF-238GG healthy individuals (36).

In addition to the TNF-238 variant, other TNF- $\alpha$ promoter polymorphisms may have a transcriptional effect. The most well studied at position -308 (37) is found to be associated with severe forms of infectious diseases $(38,39)$. However, conflicting data exist about its functionality $(22,40,41,42)$.

In addition to putative functional relevant promoter/enhancer polymorphisms, other mechanisms may account for differential TNF- $\alpha$ production. Both in cis and in trans processes may be involved. However, besides polymorphism in the $5^{\prime}$ part of the TNF- $\alpha$ gene, heterogeneity in the 3' UTR, which might indicate in cis (post) translational interference in TNF- $\alpha$ production, has not been reported. Alternatively, it is also possible that tightly linked and yet unidentified alleles at other loci modify the production or activity of TNF- $\alpha$. Since TNF- $\alpha$ production has been suggested as being MHC associated, the major component responsible for differential TNF- $\alpha$ production may reside within the MHC locus. This locus harbors a number of genes whose products are (in)directly involved in the biosynthesis of TNF- $\alpha$. A candidate gene is the SAPK-2 (stress-activated protein kinase-2) gene encoding a kinase involved in the regulation of cytokine production (43). Other candidates are the I- $\kappa \mathrm{B} / \mathrm{NF}-\kappa \mathrm{B}$-like genes IKBL (44) and G9a (45), which may play crucial roles in inducible transcriptional gene activation. Mutations affecting the expression of these genes or the activity of their gene products could have an impact on the expression of a wide range of cytokine genes, including the gene encoding TNF- $\alpha$, and consequently contribute to disease susceptibility and/or determine disease outcome.

\section{Acknowledgments}

We are grateful to Dr. Wiepke Drossaers-Bakker for establishing the cohort organization, Drs. Koos Zwinderman and Ingrid Meulenbelt for statistical assistance, and Dr. Irina Udalova for providing us with the $-1173 /+130$ TNF- $\alpha$ promoter/enhancer constructs. This project was funded with Federal funds from Het nationaal Reumafonds and the National Cancer Institute, National Institutes of Health, under Contract no. N01-CO-56000. 


\section{References}

1. Elliott MJ, Maini R, Feldmann M, et al. (1994) Randomised double-blind comparison of chimeric monoclonal antibody to tumour necrosis factor $\alpha$ (cA2) versus placebo in rheumatoid arthritis. Lancet 344: 1105-1110.

2. Elliott MJ, Maini RN, Feldmann M, et al. (1994) Repeated therapy with monoclonal antibody to tumour necrosis factor $\alpha$ (cA2) in patients with rheumatoid arthritis. Lancet 344: 1125-1 127.

3. Keffer J, Probert L, Cazlaris H, Georgopoulos S, Kaslaris E, Kioussis D, Kollias G. (1991) Transgenic mice expressing human tumour necrosis factor: a predictive genetic model of arthritis. EMBO J. 10: 4025-4031.

4. Marino MW, Dunn A, Grail D, et al. (1997) Characterization of tumor necrosis factor-deficient mice. Proc. Natl. Acad. Sci. U.S.A. 94: 8093-8098.

5. Amiot F, Boussadia O, Cases S, et al. (1997) Mice heterozygous for a deletion of the tumor necrosis factor- $\alpha$ and lymphotoxin- $\alpha$ genes: biological importance of a non-linear response of tumor necrosis factor- $\alpha$ to gene dosage. Eur. J. Immunol. 27: 1035-1042.

6. Economou JS, Rhoades K, Essner R, McBride WH, Gasson JC, Morton D. (1989) Genetic analysis of the human tumor necrosis factor $\alpha$ /cachectin promoter region in a macrophage cell line. J. Exp. Med. 170: 321-326.

7. Goldfeld AE, Doyle C, Maniatis T. (1990) Human tumor necrosis factor $\alpha$ gene regulation by virus and lipopolysaccharide. Proc. Natl. Acad. Sci. U.S.A. 87: 9769-9773.

8. Beutler B. (1992) Application of transcriptional and posttranscriptional reporter constructs to the analysis of tumor necrosis factor gene regulation. Am. J. Med. Sci. 303: 129-133.

9. Jongeneel CV. (1994) Regulation of the TNF $\alpha$ gene. Prog. Clin. Biol. Res. 388: 367-381.

10. van Zeben D, Hazes JMW, Zwinderman AH, et al. (1991) Association of HLA-DR4 with a more progressive disease course in patients with rheumatoid arthritis. Results of a follow-up study. Arthritis Rheum. 43: 822-830.

11. D'Alfonso S, Momigliano Richiardi P. (1994) A polymorphic variation in a putative regulation box of the TNFA promoter region. Immunogenetics 39: $150-154$.

12. Brinkman BMN, Huizinga TWJ, Kurban SS, et al. (1997) Tumour necrosis factor $\alpha$ gene polymorphisms in rheumatoid arthritis: association with susceptibility to, or severity of, disease? $\mathrm{Br} . \mathrm{J}$. Rheumatol. 36: 516-521.

13. Vinasco J, Beraun Y, Nieto A, et al. (1997) Polymorphism at the TNF loci in rheumatoid arthritis. Tissue Antigens 49: 74-78.

14. Huizinga TWJ, Westendorp RGJ, Bollen ELEM, et al. (1997) TNF- $\alpha$ polymorphisms, production and susceptibility to multiple sclerosis in different groups of patients. J. Neuroimmunol. 72: 149-153.

15. D'Alfonso S, Momigliano Richiardi P. (1996) An intragenic polymorphism in the human tumor necrosis factor alpha (TNFA) chain-encoding gene. Immunogenetics 44: 321-322.

16. Höhler T, Kruger A, Schneider PM, et al. (1997) A TNF- $\alpha$ promoter polymorphism is associated with juvenile onset psoriasis and psoriatic arthritis. J. Invest. Dermatol. 109: 562-565.

17. Conway DJ, Holland MJ, Bailey RL, et al. (1997) Scarring trachoma is associated with polymorphism in the tumor necrosis factor alpha (TNF- $\alpha$ ) gene promoter and with elevated TNF- $\alpha$ levels in tear fluid. Infection Immunity 65: 1003-1006.

18. Grove J, Daly AK, Bassendine MF, Day CP. (1997) Association of a tumor necrosis factor promoter polymorphism with susceptibility to alcoholic steatohepatitis. Hepatology 26: 143-146.

19. van Zeben D, Hazes JM, Zwinderman AH, Vandenbroucke JP, Breedveld FC. (1994) The severity of rheumatoid arthritis: a 6-year follow-up study of younger women with symptoms of recent onset. J. Rheumatol. 21: 1620-1625.

20. Arnett FC, Edworthy SM, Bloch DA, et al. (1988) The American Rheumatism Association 1987 revised criteria for the classification of rheumatoid arthritis. Arthritis Rheum. 31: 315-324.

21. van der Heijde DM, van Leeuwen MA, van Riel PL, van de Putte LB. (1995) Radiographic progression on radiographs of hands and feet during the first 3 years of rheumatoid arthritis measured according to Sharp's method (van der Heijde's modification). J. Rheumatol. 22: 1792-1796.

22. Brinkman BMN, Zuijdgeest D, Kaijzel EL, Breedveld FC, Verweij CL. (1996) Relevance of the tumor necrosis factor alpha (TNF $\alpha$ ) -308 promoter polymorphism in TNF $\alpha$ gene regulation. J. Imflam. 46: $32-41$.

23. Nordeen SK. (1988) Luciferase reporter gene vectors for analysis of promoters and enhancers. BioTechniques 6: 454-457.

24. Sambrook J, Fritsch EF, Maniatis T. (1989) Molecular Cloning. A Laboratory Manual. Cold Spring Laboratory Press, Cold Spring, NY.

25. Sundstrom C, Nilsson K. (1976) Establishment and characterization of a human histiocytic cell line (U-937). Int. J. Cancer 17: 565-577.

26. Ziegler-Heitbrock HWL, Thiel E, Fütterer A, Herzog V, Wirtz A, Riethmüller G. (1988) Establishment of a human cell line (Mono Mac 6) with characteristics of mature monocytes. Int. J. Cancer 41: 456-461.

27. Hill WG. (1974) Estimation of linkage disequilibrium in randomly mating populations. Heredity 33: 229-239.

28. Meulenbelt I, Williams CJ, Te Koppele JM, Van de Giessen GC, Slagboom PE. (1996) Population haplotype analysis and evolutionary relations of the COL2Al. Ann. Hum. Genet. 60: 189-199. 
29. Hamann A, Mantzoros C, Vidal-Puig A, Flier JS. (1995) Genetic variability in the TNF- $\alpha$ promoter is not associated with type II diabetes mellitus (NIDDM). Biochem. Biophys. Res. Commun. 211: 833-839.

30. D'Alfonso S, Colombo G, Della Bella S, Scorza R, Momigliano-Richiardi P. (1996) Association between polymorphisms in the TNF region and systemic lupus erythematosus in the Italian population. Tissue Antigens 47: 551-555.

31. Fong C-LW, Siddiqui AH, Mark DF. (1994) Identification and characterization of a novel repressor site in the human tumor necrosis factor $\alpha$ gene. Nucl. Acid Res. 22: 1108-1114.

32. Udalova IA, Knight JC, Vidal V, Nedospasov SA, Kwiatkowski D. (1998) Complex NF-kappaB interactions at the distal tumor necrosis factor promoter region in human monocytes. J. Biol. Chem. 273: $21178-21186$.

33. Bendtzen K, Morling N, Fomsgaard A, et al. (1988) Association between HLA-DR2 and production of tumour necrosis factor $\alpha$ and Interleukin 1 by mononuclear cells activated by lipopolysaccharide. Scand. J. Immunol. 28: 599-606.

34. Jacob CO, Fronek Z, Lewis GD, Koo M, Hansen JA, McDevitt HO. (1990) Heritable major histocompatibility complex class II-associated differences in production of tumor necrosis factor $\alpha$ : relevance to genetic predisposition to systemic lupus erythematosus. Proc. Natl. Acad. Sci. U.S.A. 87: 1233-1237.

35. Philip R, Epstein LB. (1986) Tumour necrosis factor as immunomodulator and mediator of monocyte cytotoxicity induced by itself, $\boldsymbol{\gamma}$-interferon and interleukin-1. Nature 323: 86-89.

36. Pociot F, D'Alfonso S, Compasso S, Scorza R, and Richiardi PM. (1995) Functional analysis of a new polymorphism in the human TNF $\alpha$ gene promoter. Scand. J. Immunol. 42: 501-504.

37. Wilson AG, de Vries N, Pociot F, Di Giovine FS, van der Putte LBA, Duff GW. (1993) An allelic polymorphism within the human tumor necrosis factor $\alpha$ promoter region is strongly associated with HLA A1, B8, and DR3 alleles. J. Exp. Med. 177: $557-560$.

38. McGuire W, Hill AVS, Allsopp CEM, Greenwood BM, Kwiatkowski D. (1994) Variation in the TNF- $\alpha$ promoter region associated with susceptibility to cerebral malaria. Nature 371: 508-511.

39. Cabrera M, Shaw MA, Sharples C, et al. (1995) Polymorphism in tumor necrosis factor genes associated with mucocutaneous leishmaniasis. $J$. Exp. Med. 182: 1259-1264.

40. Wilson AG, Symons JA, McDowell TL, McDevitt HO, Duff GW. (1997) Effects of a polymorphism in the human tumor necrosis factor $\alpha$ promoter on transcriptional activation. Proc. Natl. Acad. Sci. U.S.A. 94: 3195-3199.

41. Kroeger KM, Carville KS, Abraham LJ. (1997) The -308 tumor necrosis factor- $\alpha$ promoter polymorphism effects transcription. Mol. Immunol. 34: 391399.

42. Stüber F, Udalova IA, Book M, et al. (1996) -308 Tumor necrosis factor (TNF) polymorphism is not associated with survival in severe sepsis and is unrelated to lipopolysaccharide inducibility of the human TNF promoter. J. Inflam. 46: 42-50.

43. McDonnell PC, DiLella AG, Lee JC, Young PR. (1995) Localization of the human stress responsive MAP kinase-like CSAIDs binding protein (CSBP) gene to chromosome 6p21.3/21.1. Genomics 28: 301-302.

44. Albertella MR, Campbell RD. (1994) Characterization of a novel gene in the human major histocompatibility complex of the I kappa B family of proteins. Hum. Mol. Genet. 3: 793-799.

45. Milner CM, Campbell RD. (1993) The G9a gene in the human major histocompatibility complex encodes a novel protein containing ankyrin-like repeats. Biochem. J. 290: 811-818. 